\title{
In vivo Analysis of Rhizobacteria and their Supernatants for Control of Charcoal Rot of Sorghum
}

\author{
Vinayaka A. Bannur $^{1 *}$, S.N. Chattannavar ${ }^{1}$ and P.U. Krishnaraj ${ }^{2}$ \\ ${ }^{1}$ Plant Pathology, All India Coordinated Sorghum Improvement Project, \\ MARS, Dharwad, India \\ ${ }^{2}$ Agricultural Microbiology, University of Agricultural Sciences Dharwad - 580 005, \\ Karnataka, India \\ *Corresponding author
}

\section{A B S T R A C T}

Keywords

Charcoal rot,

Macrophomina

phaseolina,

Rhizobacteria,

Supernatants

Article Info

Accepted:

04 August 2019

Available Online:

10 September 2019
Charcoal rot of sorghum caused by Macrophomina phaseolina is a disease of economic importance for which a high level of genetic resistance is not available. Therefore, an effort was made to manage this disease with potent rhizobacterial strains viz., AUDP 139 and AUDT 801 in CSV 8R and CSV 29R cultivars. In CSV 8R, seed soaked in supernatants of AUDP 139 for two hours recorded least charcoal rot incidence of $40.58 \%$ with highest yield of $1924.90 \mathrm{Kg} / \mathrm{ha}$ whereas in CSV 29R, seed treatment with AUDT 801 + AUDP $139 @ 3 \mathrm{~g} / \mathrm{Kg}$ of seeds recorded least disease incidence of $14.23 \%$ with highest yield of $2675.73 \mathrm{Kg} / \mathrm{ha}$. It is inferred that the use of selection of effective strains of rhizobacteria can be a useful component of integrated management of charcoal rot in sorghum.

\section{Introduction}

Sorghum bicolor (L.) Moench commonly known as "Jowar" is one of the most important millets of India belonging to the family "Poaceae". The major sorghum cultivating states are Maharashtra, Karnataka, Rajasthan, Tamil Nadu and Andhra Pradesh. It is being grown in two seasons: kharif season as a rainfed crop while in rabi season under remaining soil moisture conditions. In Karnataka, it is cultivated on 10.90 lakh hectares of which 1.16 lakh hectares in Kharif and 9.74 lakh hectares in rabi with production and productivity of 11.50 lakh tons and 1,052 $\mathrm{kg} \mathrm{ha}^{-1}$ respectively (Anon., 2017).

Charcoal rot caused by Macrophomina phaseolina (Tassi) Goid. is major disease among biotic stresses in post rainy season and it cause major losses in grain and fodder yield. In India, almost all the cultivated hybrids and varieties are susceptible to charcoal rot (Jahagirdar, 2007). Charcoal rot pathogen, $M$. 
phaseolina causes 100 per cent lodging and significant yield losses up to 64 per cent in India under post-rainy conditions in sorghum (Mughogho and Pande, 1984). The disease is well characterized by poor grain filling, premature leaf senescence and crop lodging. Internally, the stem pith of infected plants become disintegrated and the separated fibrovascular bundles are covered with the small black sclerotial bodies of the fungus which give the stem a blackened appearance, hence the name charcoal rot.

Biological control can be viewed as an alternative and safe method to control this disease as it also has additional benefit of plant growth-promotion (PGP) traits (Labuschangne et al., 2010).

Plant disease management by plant growth promoting rhizobacteria (PGPR) is one of the most effective and eco-friendly approach compared to conventional chemical control methods, and PGPRs as biocontrol agents possess certain advantages, because PGPR does not harm the environment and their application is sustainable in long run.

\section{Materials and Methods}

A field experiment on integrated disease management was laid out in charcoal rot sick plot at MARS, Dharwad in medium deep black soil having $45-60 \mathrm{~cm}$ soil depth during rabi season of 2018-19.

This trial was laid out in randomized block design (RBD) with three replications with a net plot size of $3.15 \times 4.2 \mathrm{~m}^{2}$ and sown on second fortnight of October with a spacing of $45 \times 15 \mathrm{~cm}$ using CSV $8 \mathrm{R}$ (highly susceptible for charcoal rot) and CSV 29R (moderately resistant for charcoal rot) genotypes.

AUDT 801 and AUDP 139 rhizobacterial isolates which found superior in in vitro along with reference isolate of Trichoderma harzianum were evaluated under field conditions for their efficacy to control charcoal rot.

\section{Treatment Details}

\begin{tabular}{|l|l|}
\hline Treatments & Description \\
\hline $\mathbf{T}_{\mathbf{1}}$ & AUDT 801 @ 3g/Kg of seeds \\
\hline $\mathbf{T}_{\mathbf{2}}$ & AUDT 801 @ 4g/Kg of seeds \\
\hline $\mathbf{T}_{\mathbf{3}}$ & AUDP 139 @ 3g/Kg of seeds \\
\hline $\mathbf{T}_{\mathbf{4}}$ & AUDP 139 $@ \mathrm{~g} / \mathrm{Kg}$ of seeds \\
\hline $\mathbf{T}_{\mathbf{5}}$ & AUDT 801+AUDP 139 @ 3g/Kg of seeds \\
\hline $\mathbf{T}_{\mathbf{6}}$ & AUDT 801+AUDP 139 $@ 4 \mathrm{~g} / \mathrm{Kg}$ of seeds \\
\hline $\mathbf{T}_{\mathbf{7}}$ & Seed soaking in supernatants of AUDT 801 for 2 hours \\
\hline $\mathbf{T}_{\mathbf{8}}$ & Seed soaking in supernatants of AUDP 139 for 2 hours \\
\hline $\mathbf{T}_{\mathbf{9}}$ & Trichoderma harzianum @ 4g/Kg of seeds \\
\hline $\mathbf{T}_{\mathbf{1 0}}$ & Control \\
\hline
\end{tabular}

Note: AUDT $=$ Agricultural University Dharwad Actinobacteria and AUDP $=$ Agricultural University Dharwad Pseudomonas.

Incidence of charcoal rot was recorded at crop maturity (115 days after emergence).

Each plant in a plot was split open longitudinally along with the roots with a knife for ensuring the presence or absence of charcoal rot symptoms. Percentage incidence of charcoal rot was calculated for each plot. Observations on charcoal rot parameters and yield related parameters were recorded. 


\section{Results and Discussion}

\section{Charcoal rot percentage}

In CSV 8R, seed soaking in supernatants of AUDP 139 for two hours $\left(\mathrm{T}_{8}\right)$ recorded the least charcoal rot percentage $(40.58 \%)$ with highest per cent disease reduction over control $(30.14 \%)$ and was on par with other treatments. However, significant differences were observed in all the treatments when compared with the control (58.09\%).

In CSV 29R cultivar, the least charcoal rot incidence $(14.23 \%)$ was found in seeds treated with AUDT 801 + AUDP 139 @ 3 $\mathrm{g} / \mathrm{kg}$ of seeds $\left(\mathrm{T}_{5}\right)$ with highest per cent disease reduction over control $(45.45 \%)$ and was on par with all other treatments. However, significant differences were observed in all the treatments as compared to control (26.09\%). In CSV 8R, charcoal rot percentage varied from 40.58 to $58.09 \%$ whereas in CSV 29R cultivar it ranged from 15.85 to $26.09 \%$. So, it was confirmed that CSV 29R recorded least incidence of charcoal rot compared to CSV $8 \mathrm{R}$.

In pooled analysis, it was found that seed soaking in supernatants of AUDP 139 for two hours $\left(\mathrm{T}_{8}\right)$ recorded the least charcoal rot percentage $(28.21 \%)$ and was on par with all the treatments followed by seeds treated with AUDT $801+$ AUDP 139 @ $3 \mathrm{~g} / \mathrm{kg}$ of seeds $\left(\mathrm{T}_{5}\right)$ which recorded 28.36 charcoal rot percentage. The highest pooled per cent disease reduction over control was recorded in seeds treated with AUDT 801 + AUDP 139 @ $3 \mathrm{~g} / \mathrm{kg}$ of seeds $(36.14 \%)\left(\mathrm{T}_{5}\right)$ and the maximum charcoal rot percentage was noticed in control (42.09\%) (Table 1, Fig. 1 and Plate 2).

\section{Mean Nodes Crossed (MNC)}

In CSV 8R, seeds treated with AUDT $801+$ AUDP $139 @ 3 \mathrm{~g} / \mathrm{kg}$ of seeds $\left(\mathrm{T}_{5}\right)$ recorded the least mean nodes crossed (2.40) and was on par with all the treatments except $\mathrm{T}_{7}$. However, there was significant difference among the treatments as compared to control. The highest mean nodes crossed recorded in control (3.33).

In CSV 29R, seeds treated with AUDT 801 @ $3 \mathrm{~g} / \mathrm{kg}$ of seeds $\left(\mathrm{T}_{1}\right)$ recorded the least mean nodes crossed (2.06) and was on par with all the treatments. However, there was significant difference among the treatments as compared to control. The highest mean nodes crossed recorded were in control (2.73). The mean nodes crossed varied from 2.40 to 3.33 and 2.06 to 2.73 in CSV 8R and CSV 29R respectively.

In pooled analysis, it was observed that the seeds treated with AUDT 801 @ $3 \mathrm{~g} / \mathrm{kg}$ of seeds $\left(\mathrm{T}_{1}\right)$ recorded the least mean nodes crossed (2.26) and was on par with all the treatments followed by the seeds treated with AUDT $801+$ AUDP $139 @ 3 \mathrm{~g} / \mathrm{kg}$ of seeds $\left(\mathrm{T}_{5}\right)$ and seeds treated with $T$. harzianum @ 4 $\mathrm{g} / \mathrm{kg}$ of seeds $\left(\mathrm{T}_{9}\right)$ which recorded 2.36. The maximum mean nodes crossed recorded in control (3.03) (Table 1).

\section{Mean Length of Spread (MLS)}

In CSV 8R, seeds treated with AUDT $801+$ AUDP $139 @ 3 \mathrm{~g} / \mathrm{kg}$ of seeds $\left(\mathrm{T}_{5}\right)$ recorded the least mean length of spread $(25.20 \mathrm{~cm})$ and was on par with $T_{9}, T_{1}, T_{3}, T_{6}$ and $T_{2}$. All the treatments varied significantly to control. The highest mean length of infection was observed in control $(38.60 \mathrm{~cm})$.

In CSV 29R, seeds treated with T. harzianum @ $4 \mathrm{~g} / \mathrm{kg}$ of seeds $\left(\mathrm{T}_{9}\right)$ recorded the least mean length of spread of $25.20 \mathrm{~cm}$ and was on par with all the treatments except $\mathrm{T}_{5}$. All treatments except $T_{5}$ varied significantly to control. The highest mean length of infection was observed in control $(32.53 \mathrm{~cm})$. 
The mean length of spread ranged from 25.20 $\mathrm{cm}$ to $38.60 \mathrm{~cm}$ and $25.20 \mathrm{~cm}$ to $32.53 \mathrm{~cm}$ in CSV 8R and CSV 29R respectively.

Pooled analysis revealed that, seed treatment with $T$. harzianum @ $4 \mathrm{~g} / \mathrm{kg}$ of seeds $\left(\mathrm{T}_{9}\right)$ recorded the least mean length of spread $(26.76 \mathrm{~cm})$ and was on par with all treatments. The maximum mean length of spread was observed in control $(35.56 \mathrm{~cm})$ (Table 1).

\section{Grain yield}

In case of CSV 8R, grain yield per hectare differed significantly among the treatments. The highest grain yield was recorded in seed soaking in supernatants of AUDP 139 for two hours $\left(\mathrm{T}_{8}\right)(1924.90 \mathrm{~kg} / \mathrm{ha})$ with highest per cent increase in grain yield over control (20.69 $\%$ ) followed by seeds treated with $T$. harzianum @ $4 \mathrm{~g} / \mathrm{kg}$ of seeds $\left(\mathrm{T}_{9}\right)(1902.22$ $\mathrm{kg} / \mathrm{ha})$. The lowest grain yield was recorded in control (1594.85 kg/ha).

In CSV 29R, grain yield per hectare differed significantly among the treatments. The highest grain yield was recorded in seeds treated with AUDT 801 + AUDP 139 @ 3 $\mathrm{g} / \mathrm{kg}$ of seeds $\left(\mathrm{T}_{5}\right)(2675.73 \mathrm{~kg} / \mathrm{ha})$ with highest per cent increase in grain yield over control $(33.08 \%)$ followed by seeds treated with AUDP $139 @ 3 \mathrm{~g} / \mathrm{kg}$ of seeds $\left(\mathrm{T}_{3}\right)$ $(2637.94 \mathrm{~kg} / \mathrm{ha})$. The lowest grain yield was recorded in control (2010.57 kg/ha).

The grain yield ranged from 1594.85 to $1924.20 \mathrm{~kg} / \mathrm{ha}$ and 2010.57 to $2675.73 \mathrm{~kg} / \mathrm{ha}$ in CSV 8R and CSV 29R respectively.

Pooled analysis revealed that grain yield per hectare varied significantly among the treatments.

The maximum grain yield was observed in seeds treated with AUDT 801 + AUDP 139 @ $3 \mathrm{~g} / \mathrm{kg}$ of seeds $\left(\mathrm{T}_{5}\right)(2210.87 \mathrm{~kg} / \mathrm{ha})$ with highest per cent increase in grain yield over control $(21.27 \%)$ followed by seeds treated with AUDP 139 @ $3 \mathrm{~g} / \mathrm{kg}$ of seeds $\left(\mathrm{T}_{3}\right)$ $(2183.16 \mathrm{~kg} / \mathrm{ha})$. The lowest grain yield was observed in control $(1802.71 \mathrm{~kg} / \mathrm{ha})$ (Table 2 and Fig. 2).

\section{Fodder yield}

In CSV 8R, the highest fodder yield was observed in seed soaking in supernatants of AUDP 139 for two hours $\left(\mathrm{T}_{8}\right)(2.92 \mathrm{t} / \mathrm{ha})$ and was on par with other treatments. The least fodder yield was recorded in control (2.54 t/ha).

In CSV 29R, the highest fodder yield was recorded in seeds treated with AUDT $801+$ AUDP 139 @ $3 \mathrm{~g} / \mathrm{kg}$ of seeds $\left(\mathrm{T}_{5}\right)(5.23 \mathrm{t} / \mathrm{ha})$ and was on par with other treatments. The least fodder yield was observed in control (4.04 t/ha).

The fodder yield ranged from 2.54 to $2.92 \mathrm{t} / \mathrm{ha}$ and 4.04 to $5.23 \mathrm{t} / \mathrm{ha}$ in CSV 8R and CSV 29R respectively.

Pooled analysis revealed that maximum fodder yield was recorded in seeds treated with AUDT 801 + AUDP 139 @ $3 \mathrm{~g} / \mathrm{kg}$ of seeds $\left(\mathrm{T}_{5}\right)(3.97 \mathrm{t} / \mathrm{ha})$ followed by seeds treated with AUDP $139 @ 4 \mathrm{~g} / \mathrm{kg}$ of seeds $\left(\mathrm{T}_{4}\right)$ (3.93 t/ha).

The least fodder yield was recorded in control plants (3.20 t/ha) (Table 2).

\section{Hundred seed weight}

In case of hundred seed weight there were no significant differences among the treatments in both the cultivars. However, in CSV 8R the highest hundred seed weight was observed in seeds treated with AUDT 801 + AUDP 139 @ $3 \mathrm{~g} / \mathrm{kg}$ of seeds $\left(\mathrm{T}_{5}\right)(2.74 \mathrm{~g})$ and the lowest was noticed in control $(2.35 \mathrm{~g})$. 
Table.1 Management of charcoal rot of sorghum in field conditions (charcoal rot parameters)

\begin{tabular}{|c|c|c|c|c|c|c|c|c|c|c|c|c|c|}
\hline \multirow[t]{2}{*}{ Treatments } & \multirow[t]{2}{*}{ Treatment Details } & \multicolumn{6}{|c|}{ Charcoal rot $(\%)$} & \multicolumn{3}{|c|}{ Mean nodes crossed (No.) } & \multicolumn{3}{|c|}{ Mean length of infection $(\mathrm{cm})$} \\
\hline & & CSV 8R & $\begin{array}{l}\text { Per cent } \\
\text { disease } \\
\text { reductio } \\
\text { n over } \\
\text { control }\end{array}$ & CSV29R & $\begin{array}{l}\text { Per cent } \\
\text { disease } \\
\text { reductio } \\
\text { n over } \\
\text { control }\end{array}$ & $\begin{array}{l}\text { Pooled } \\
\text { charcoal } \\
\text { rot }(\%)\end{array}$ & $\begin{array}{l}\text { Pooled } \\
\text { per cent } \\
\text { disease } \\
\text { reductio } \\
\text { n over } \\
\text { control }\end{array}$ & $\begin{array}{l}\text { CSV } \\
8 R\end{array}$ & $\begin{array}{l}\text { CSV } \\
29 R\end{array}$ & Pooled & $\begin{array}{l}\text { CSV } \\
8 R\end{array}$ & $\begin{array}{l}\text { CSV } \\
29 R\end{array}$ & Pooled \\
\hline $\mathbf{T}_{1}$ & $\begin{array}{l}\text { AUDT } 801 @ 3 \mathrm{~g} / \mathrm{kg} \text { of } \\
\text { seeds }\end{array}$ & $\begin{array}{c}44.83 \\
(41.97)^{*}\end{array}$ & 22.82 & $\begin{array}{c}17.74 \\
(24.86)\end{array}$ & 32.00 & $\begin{array}{c}31.28 \\
(33.41)\end{array}$ & 27.41 & 2.46 & 2.06 & 2.26 & 28.20 & 26.54 & 27.37 \\
\hline$T_{2}$ & $\begin{array}{l}\text { AUDT } 801 @ 4 \text { g/kg of } \\
\text { seeds }\end{array}$ & $\begin{array}{c}44.72 \\
(41.85)\end{array}$ & 23.01 & $\begin{array}{l}18.54 \\
(25.45)\end{array}$ & 28.93 & $\begin{array}{c}31.63 \\
(33.65)\end{array}$ & 25.97 & 2.63 & 2.33 & 2.48 & 30.33 & 26.07 & 28.20 \\
\hline $\mathbf{T}_{3}$ & AUDP 139 @ 3g/kg of seeds & $\begin{array}{c}43.65 \\
(41.30)\end{array}$ & 24.85 & $\begin{array}{c}15.91 \\
(23.26)\end{array}$ & 39.01 & $\begin{array}{c}29.78 \\
(32.28)\end{array}$ & 31.93 & 2.66 & 2.46 & 2.56 & 30.06 & 27.80 & 28.93 \\
\hline $\mathbf{T}_{4}$ & $\begin{array}{l}\text { AUDP } 139 @ 4 \mathrm{~g} / \mathrm{kg} \text { of } \\
\text { seeds }\end{array}$ & $\begin{array}{c}47.89 \\
(43.78)\end{array}$ & 17.55 & $\begin{array}{l}18.05 \\
(25.14)\end{array}$ & 30.81 & $\begin{array}{c}32.97 \\
(34.46)\end{array}$ & 24.18 & 2.60 & 2.26 & 2.43 & 31.06 & 28.71 & 29.88 \\
\hline $\mathbf{T}_{5}$ & $\begin{array}{l}\text { AUDT } 801+\text { AUDP } 139 @ \\
3 \mathrm{~g} / \mathrm{kg} \text { of seeds }\end{array}$ & $\begin{array}{c}42.50 \\
(40.67)\end{array}$ & 26.83 & $\begin{array}{c}14.23 \\
(22.08)\end{array}$ & 45.45 & $\begin{array}{c}28.36 \\
(31.37)\end{array}$ & 36.14 & 2.40 & 2.33 & 2.36 & 25.20 & 29.40 & 27.30 \\
\hline $\mathbf{T}_{6}$ & $\begin{array}{l}\text { AUDT } 801+A U D P 139 @ 4 \\
\text { g/kg of seeds }\end{array}$ & $\begin{array}{c}49.25 \\
(44.57)\end{array}$ & 15.21 & $\begin{array}{c}16.90 \\
(24.27)\end{array}$ & 35.22 & $\begin{array}{c}33.07 \\
(34.42)\end{array}$ & 25.21 & 2.53 & 2.46 & 2.49 & 30.26 & 26.20 & 28.23 \\
\hline $\mathbf{T}_{7}$ & $\begin{array}{l}\text { Seed soaking in supernatants } \\
\text { of AUDT } 801 \text { for two hours }\end{array}$ & $\begin{array}{c}48.76 \\
(44.28)\end{array}$ & 16.06 & $\begin{array}{l}18.11 \\
(25.17)\end{array}$ & 30.58 & $\begin{array}{c}33.43 \\
(34.72)\end{array}$ & 23.32 & 2.76 & 2.20 & 2.48 & 31.20 & 28.23 & 29.71 \\
\hline $\mathbf{T}_{8}$ & $\begin{array}{l}\text { Seed soaking in supernatants } \\
\text { of AUDP } 139 \text { for two hours }\end{array}$ & $\begin{array}{c}40.58 \\
(39.39)\end{array}$ & 30.14 & $\begin{array}{c}15.85 \\
(23.14)\end{array}$ & 39.24 & $\begin{array}{c}28.21 \\
(31.26)\end{array}$ & 34.69 & 2.68 & 2.26 & 2.47 & 32.40 & 27.58 & 29.99 \\
\hline $\mathbf{T}_{9}$ & $\begin{array}{l}\text { Trichoderma harzianum @ } 4 \\
\text { g/kg of seeds }\end{array}$ & $\begin{array}{c}42.26 \\
(40.41)\end{array}$ & 27.25 & $\begin{array}{c}20.97 \\
(27.19)\end{array}$ & 19.62 & $\begin{array}{c}31.61 \\
(33.80)\end{array}$ & 23.43 & 2.60 & 2.13 & 2.36 & 28.33 & 25.20 & 26.76 \\
\hline $\mathbf{T}_{10}$ & Control & $\begin{array}{c}58.09 \\
(49.77)\end{array}$ & - & $\begin{array}{c}26.09 \\
(30.17)\end{array}$ & - & $\begin{array}{c}42.09 \\
(39.97)\end{array}$ & - & 3.33 & 2.73 & 3.03 & 38.60 & 32.53 & 35.56 \\
\hline & S.Em. \pm & 2.73 & & 1.32 & & 2.02 & & 0.10 & 0.13 & 0.11 & 1.89 & 1.24 & 1.56 \\
\hline & CD@ @ & 8.13 & & 3.95 & & 6.04 & & 0.32 & 0.41 & 0.36 & 5.64 & 3.69 & 4.67 \\
\hline & $\mathrm{CV}(\%)$ & 11.06 & & 9.16 & & 10.11 & & 7.08 & 10.27 & 8.67 & 10.76 & 7.74 & 9.25 \\
\hline
\end{tabular}




\section{Int.J.Curr.Microbiol.App.Sci (2019) 8(9): 88-96}

Table.2 Management of charcoal rot of sorghum in field conditions (yield parameters)

\begin{tabular}{|c|c|c|c|c|c|c|c|c|c|c|c|c|c|}
\hline \multirow[t]{2}{*}{ Treatments } & \multirow[t]{2}{*}{ Treatment Details } & \multicolumn{6}{|c|}{ Grain Yield (kg/ha) } & \multicolumn{3}{|c|}{ Fodder Yield (t/ha) } & \multicolumn{3}{|c|}{100 seed weight (gms) } \\
\hline & & CSV 8R & $\begin{array}{l}\text { Per cent } \\
\text { increase in } \\
\text { grain yield } \\
\text { over } \\
\text { control }\end{array}$ & CSV 29R & $\begin{array}{l}\text { Per cent } \\
\text { increase in } \\
\text { grain yield } \\
\text { over } \\
\text { control }\end{array}$ & $\begin{array}{l}\text { Pooled } \\
\text { grain } \\
\text { yield }\end{array}$ & $\begin{array}{l}\text { Pooled per } \\
\text { cent } \\
\text { increase in } \\
\text { grain yield } \\
\text { over control }\end{array}$ & CSV 8R & $\begin{array}{l}\text { CSV } \\
29 R\end{array}$ & Pooled & $\begin{array}{l}\text { CSV } \\
8 R\end{array}$ & $\begin{array}{l}\text { CSV } \\
29 R\end{array}$ & Pooled \\
\hline $\mathbf{T}_{1}$ & AUDT801@3g/kg of seeds & 1655.32 & 3.79 & 2151.67 & 7.01 & 1903.49 & 5.40 & 2.76 & 4.92 & 3.84 & 2.58 & 2.83 & 2.70 \\
\hline $\mathbf{T}_{2}$ & AUDT801@4 g/kg of seeds & 1743.51 & 9.32 & 2136.55 & 6.26 & 1940.03 & 7.79 & 2.81 & 4.92 & 3.86 & 2.46 & 2.74 & 2.60 \\
\hline $\mathbf{T}_{3}$ & AUDP139@3g/kg of seeds & 1728.39 & 8.37 & 2637.94 & 31.20 & 2183.16 & 19.78 & 2.82 & 5.03 & 3.92 & 2.66 & 2.72 & 2.69 \\
\hline $\mathbf{T}_{4}$ & AUDP139@4 g/kg of seeds & 1693.11 & 6.16 & 2207.10 & 9.77 & 1950.10 & 7.96 & 2.75 & 5.11 & 3.93 & 2.42 & 2.73 & 2.57 \\
\hline $\mathbf{T}_{5}$ & $\begin{array}{l}\text { AUDT 801+AUDP } 139 @ \\
\text { 3g/kg of seeds }\end{array}$ & 1746.02 & 9.47 & 2675.73 & 33.08 & 2210.87 & 21.27 & 2.71 & 5.23 & 3.97 & 2.74 & 3.10 & 2.92 \\
\hline $\mathbf{T}_{6}$ & $\begin{array}{l}\text { AUDP 801+AUDP } 139 @ 4 \\
\text { g/kg of seeds }\end{array}$ & 1690.59 & 6.00 & 2214.66 & 10.15 & 1952.62 & 8.07 & 2.69 & 4.83 & 3.76 & 2.63 & 2.85 & 2.74 \\
\hline $\mathbf{T}_{7}$ & $\begin{array}{l}\text { Seed soaking in supernatants } \\
\text { of AUDT } 801 \text { for two hours }\end{array}$ & 1602.38 & 0.47 & 2249.95 & 11.90 & 1926.16 & 6.19 & 2.74 & 4.77 & 3.75 & 2.64 & 2.88 & 2.76 \\
\hline $\mathbf{T}_{8}$ & $\begin{array}{l}\text { Seed soaking in supernatants } \\
\text { of AUDP } 139 \text { for two hours }\end{array}$ & 1924.90 & 20.69 & 2393.54 & 19.04 & 2159.22 & 19.86 & 2.92 & 4.56 & 3.74 & 2.54 & 2.81 & 2.67 \\
\hline $\mathbf{T}_{9}$ & $\begin{array}{l}\text { Trichoderma harzianum @ } 4 \\
\text { g/kg of seeds }\end{array}$ & 1902.22 & 19.27 & 2182.42 & 8.54 & 2042.32 & 13.90 & 2.86 & 4.71 & 3.78 & 2.55 & 2.93 & 2.74 \\
\hline $\mathbf{T}_{10}$ & Control & 1594.85 & - & 2010.57 & - & 1802.71 & & 1.94 & 3.60 & 2.77 & 2.35 & 2.61 & 2.48 \\
\hline & S. Em. \pm & 0.14 & & 0.34 & & 0.24 & & 0.15 & 0.32 & 0.23 & 0.08 & 0.10 & 0.09 \\
\hline & CD @ 5\% & 0.41 & & 1.01 & & 0.71 & & 0.46 & 0.95 & 0.70 & 0.26 & 0.30 & 0.28 \\
\hline & $\mathrm{CV}(\%)$ & 10.65 & & 19.47 & & 15.06 & & 9.85 & 11.51 & 10.68 & 6.01 & 6.28 & 6.14 \\
\hline
\end{tabular}


Fig.1 Management of charcoal rot of sorghum (Per cent charcoal rot)

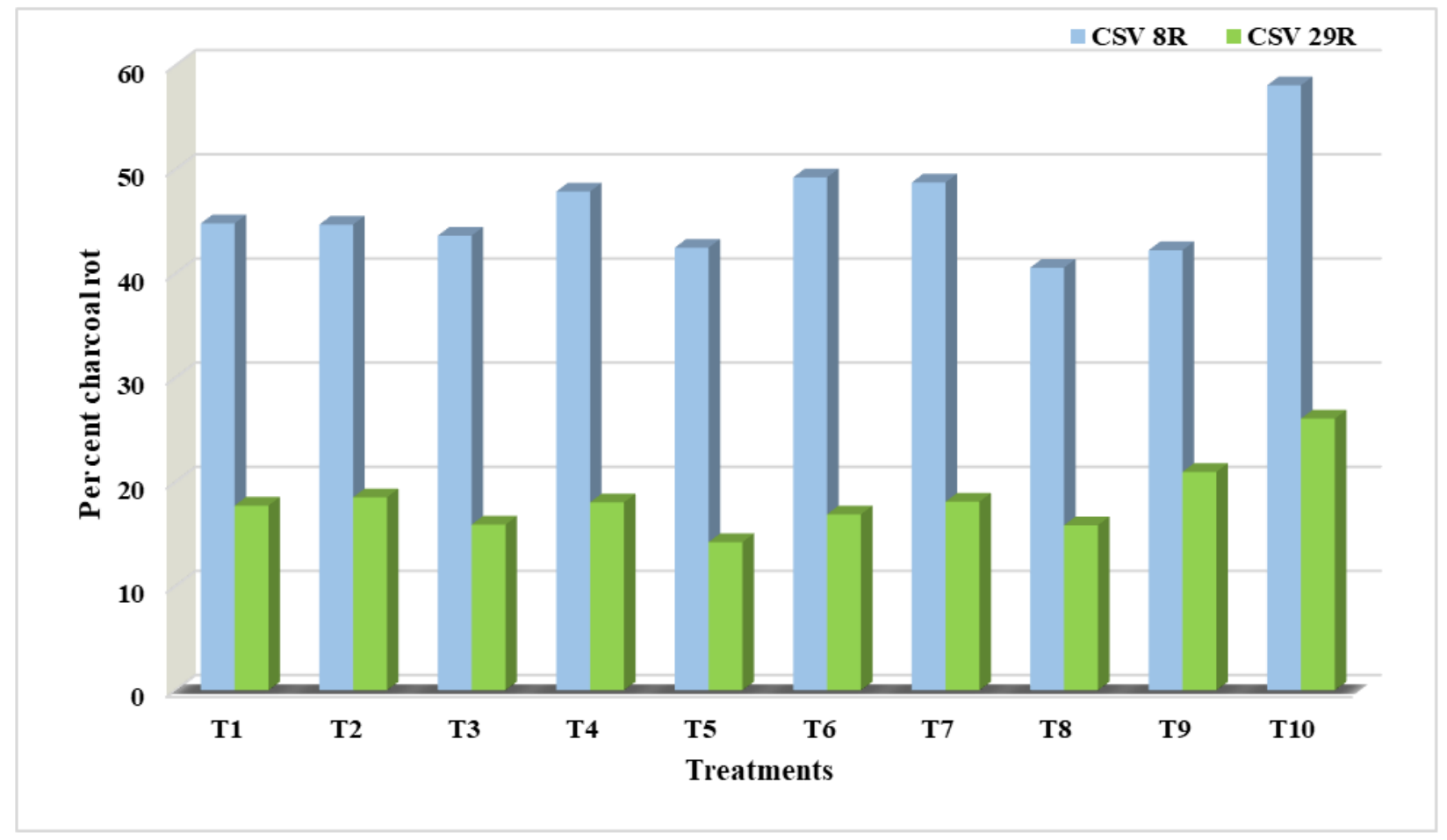

Fig.2 Management of charcoal rot of sorghum (yield)

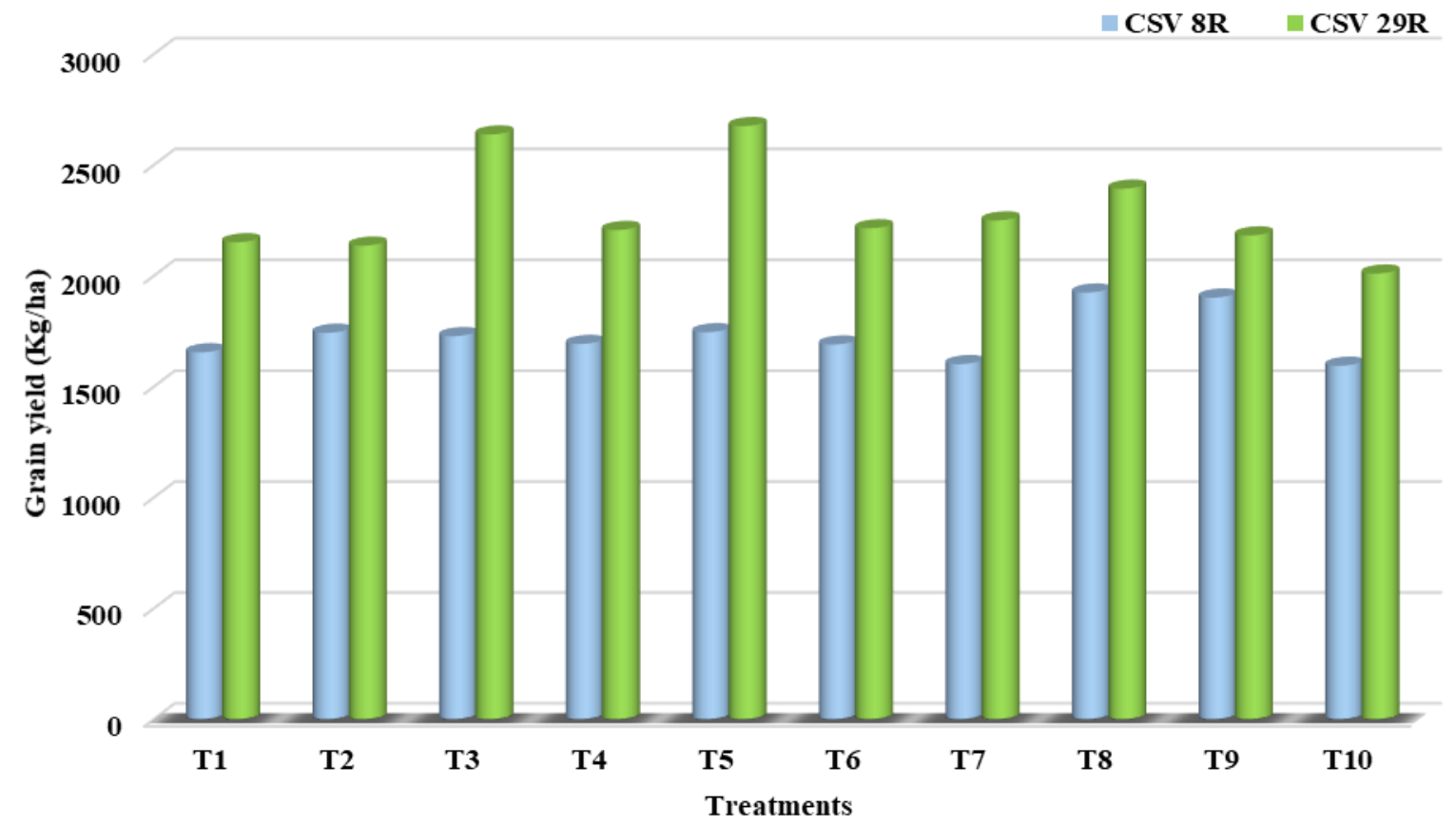


Plate.1 Lodging of the crop

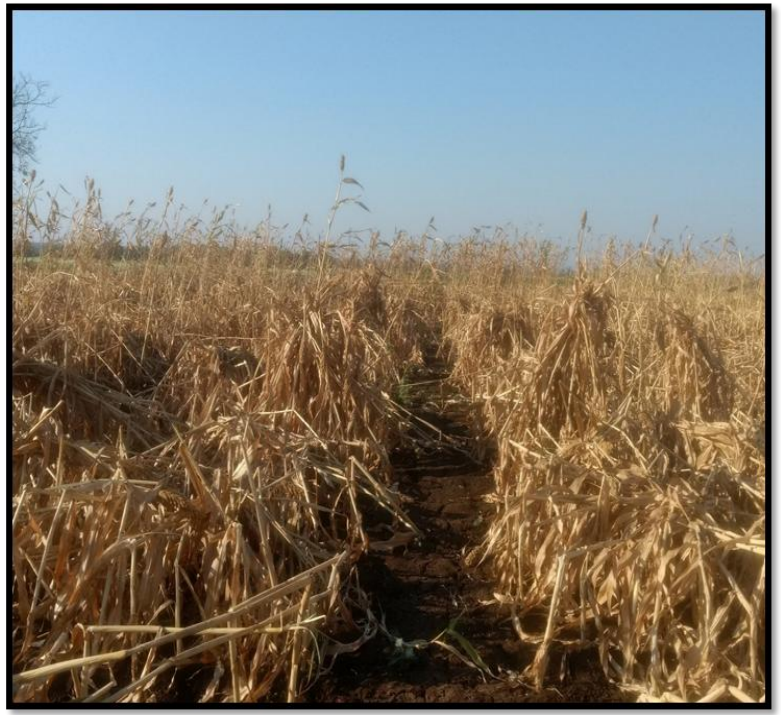

CSV 8R

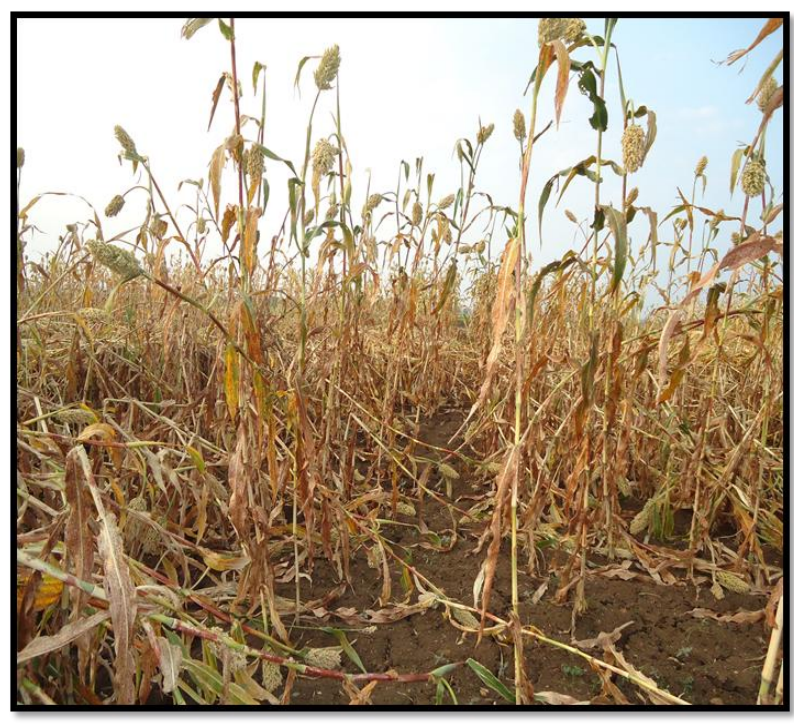

CSV 29R

Plate.2 Effective treatments for charcoal rot

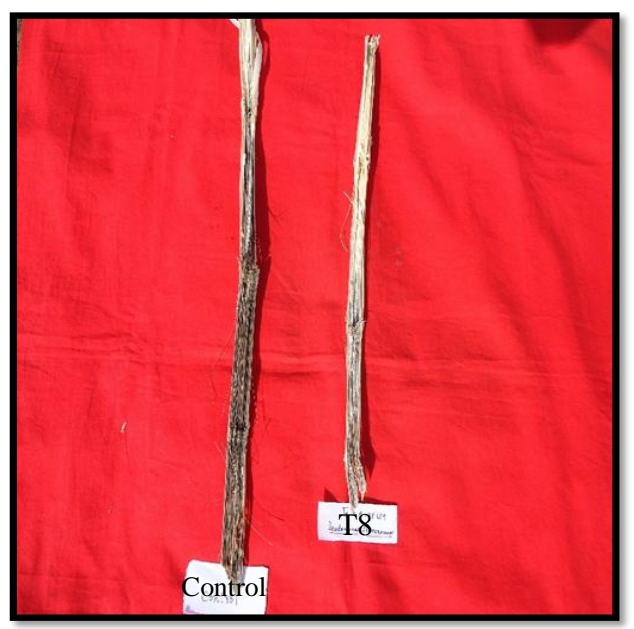

In CSV 29R, the highest hundred seed weight was recorded in seeds treated with AUDT 801 + AUDP 139 @ 3 g/kg of seeds $\left(\mathrm{T}_{5}\right)(3.10 \mathrm{~g})$ and the lowest was observed in control (2.61 g).

Pooled analysis revealed that there were no significant differences among the treatments as they were on par with each other. However, numerically the highest hundred

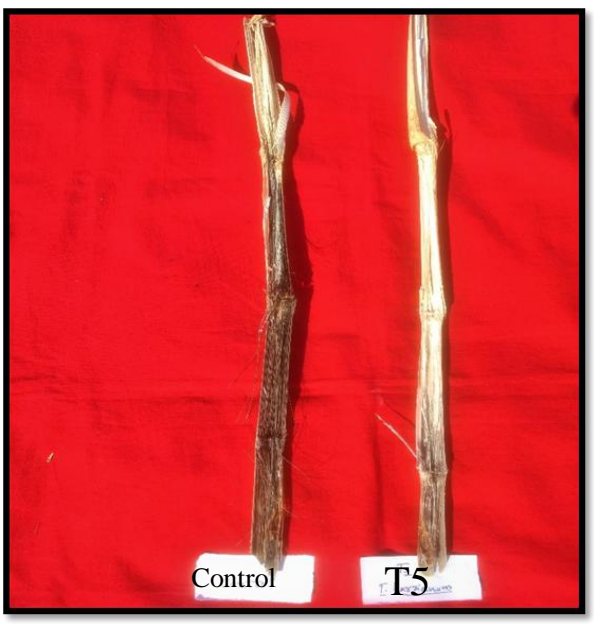

seed weight was recorded in AUDT $801+$ AUDP $139 @ 3 \mathrm{~g} / \mathrm{kg}$ of seeds $\left(\mathrm{T}_{5}\right)(2.92 \mathrm{~g})$ followed by seed soaking in supernatants for two hours for AUDT $801\left(\mathrm{~T}_{7}\right)(2.76 \mathrm{~g})$. The lowest hundred seed weight was recorded in control (2.48 g) (Table 2).

It is inferred that the treatment AUDT $801+$ AUDP $139 @ 3 \mathrm{~g} / \mathrm{kg}$ of seeds $\left(\mathrm{T}_{5}\right)$ was found better for reducing the charcoal rot 
percentage, increasing both grain yield and fodder yield along with increase in test weight i.e., hundred seed weight.

The results thus obtained support the similar work done by Das et al., (2008) who reported that among three different Pseudomonas chlororaphis strains viz., SRB 127, SRB 129 and SRB 288, Pseudomonas chlororaphis SRB 127 was the most efficient in control of charcoal rot of sorghum. Effective colonization and survival in sorghum rhizosphere, production of extracellular antibiotic and different metabolites with antagonistic properties, volatile substances like hydrogen cyanide ( $\mathrm{HCN}$ ) and siderophore production which limit the iron concentration for pathogen together contributed to the disease control. Combined application of AUDP 139 and AUDT 801 resulted in synergistic effect on suppression of charcoal rot and enhanced test weight. Similar findings in synergism was earlier reported by Imran and Shaukat (2002) in control of root rot by M. phaseolina in tomato.

\section{References}

Anonymous., 2017, Selected state/seasonwise area, production and productivity of jowar in India. Ministry of Agriculture and Farmers' Welfare,
Govt. of India, New Delhi, pp. 97-99.

Das, I. K., Indira, S., Annapurna, A., Prabhakar and Seetharama, N., 2008, Bio control of charcoal rot in sorghum by fluorescent pseudomonads associated with the rhizosphere. Crop Prot., 27: 1407-1414.

Imran, A. S. and Shaukat, S. S., 2002, Mixtures of plant disease suppressive bacteria enhance biological control of multiple tomato pathogens. Biol. Fertil. Soils, 36: 260-268.

Jahagirdar, S., 2007, Present status and future research needs on the management of charcoal rot of sorghum. Agric. Rev., 28(3): 197-206.

Labuschagne, N., Pretorius, T. and Idris, A. H., 2010, Plant growth promoting rhizobacteria as biocontrol agents against soil borne plant diseases. Academia, 1-13.

Mughogho, L. K. and Pande, S., 1984, Charcoal rot of sorghum. In: Sorghum Root and Stalk Rots, Critical Review. Proceedings of Consultative Group Discussion of Research on Enemies and Strategies for Control of Sorghum Root and Stalk Rot Diseases, 27 November 2 December, 1983, Bellagio, Italy, ICRISAT, Patancheru, Andhra Pradesh, India, pp. 11-24.

\section{How to cite this article:}

Vinayaka A. Bannur, S.N. Chattannavar and Krishnaraj, P.U. 2019. In vivo Analysis of Rhizobacteria and their Supernatants for Control of Charcoal Rot of Sorghum. Int.J.Curr.Microbiol.App.Sci. 8(09): 88-96. doi: https://doi.org/10.20546/ijcmas.2019.809.013 